\title{
The Rising Paradigm of Pentecostapreneurship in Nigeria: Impacts on National Development
}

\author{
Ngozi N. Iheanacho, Chidiebere A. Ughaerumba \\ University of Port Harcourt, Port Harcourt, Nigeria \\ Email: drngoziiheanacho@yahoo.com, mbaruga@gmail.com
}

Received 13 May 2016; accepted 27 August 2016; published 30 August 2016

Copyright @ 2016 by authors and Scientific Research Publishing Inc.

This work is licensed under the Creative Commons Attribution International License (CC BY). http://creativecommons.org/licenses/by/4.0/

(c) (i) Open Access

\begin{abstract}
For over four decades now, the Pentecostal brand of Christianity has remained on steady rise and boom in Nigeria. The churches flourish as vibrant business enterprises-the founders and leaders-operate in the praxis of entrepreneurs. The number of such churches operating in the frame of pentecostapreneurship is so many that investigation into the phenomenon is necessary. Relying on phenomenological method of enquiry, skewed in qualitative analysis, the paper identified the pentecostapreneurship praxis as veritable socio-economic activity for national development. The operational strategies revolve around crusade, revival and outreach programmes.
\end{abstract}

\section{Keywords}

Pentecostalism, Pentecostapreneurship, Evangeconomics, Church, Nigeria, National Development

\section{Introduction}

The role of religious factor to societal development cannot be ignored in any society. Nigeria has a very rich religious environment replete with diverse religious groups, movements and denominations with a market of current and potential adherents. Hence, it is not an overstatement on some scholars' evaluation of this phenomenon that Nigerians are deeply religious people (Mbiti, 1969). It is religion everywhere and the Nigerian space is alive with varieties of religious programmes, multiplicity of religious affiliations, faith systems, mosques, churches and houses of prayer and different categories of religious ministers.

Christianity and Islam are the two most flourishing and influential religions in Nigeria. For Mbachirin (2006: p.1), the number of Muslims in Nigeria is far greater than the number of Muslims in any Arab nation, including

How to cite this paper: Iheanacho, N. N., \& Ughaerumba, C. A. (2016). The Rising Paradigm of Pentecostapreneurship in Nigeria: Impacts on National Development. Open Journal of Philosophy, 6, 288-298. 
Egypt. Similarly, the number of Christians in Nigeria is the second only to Brazil which has the largest number of Christians in the world (Mbachirin, 2006: p. 1). Anglican Communion has more members in Nigeria than anywhere else in the world. Catholics in Nigeria will soon outnumber those in Brazil. Also, the rate at which Pentecostalism is growing in Nigeria is at the moment faster than what obtains in other parts of the world (Mbachirin, 2006: p. 1).

Pentecostalism is one of the extended offshoots of Reformation in Christianity. Reformation (mid-1600-1900) led to the birth of Protestantism and other forms of evangelical denominational strands. Evangelical Protestantism in general accounts for the most dynamic branches of the traditions emanating from the Reformation (Berger, 2008). As evangelical Protestant denominations split along ideological lines, new conservative tendencies such as fundamentalism and Pentecostalism were born. Since its emergence, Pentecostalism has become one of the world's fastest growing religious movements (Barker, 2007: p. 407) with the fastest growing population of Christians (Barrett \& Johnson, 2001: p. 25) in the contemporary world. It is expanding most rapidly to different parts of the world including North and Latin America, Asia and Africa and has over five hundred and thirty-three million (533) adherents (Barrett \& Johnson, 2001: p. 25).

Pentecostal churches in Nigeria are breeding, brooding and hatching, and springing up like maggots on daily basis (Obiora, 1998: p. 1). All nooks and crannies of the country, especially, in the Southern region are punctuated with countless number of churches. The number of churches and prayer houses belonging to Pentecostal tradition are simply overwhelming (Ihejirika, 2004: p. 1). As at 1998, Obiora (1998: pp. 21-39)'s statistics of Pentecostal churches in Lagos, Ibadan and Benin City recorded one thousand and eighteen (1018) different churches. According to Christian Today (online magazine), Nigeria has about 3.9 million Pentecostals as at the year 2007 and considering the growth rate of this movement, the number would have approximately risen to 5 million Pentecostals. This astronomic growth and expansion raised the curiosity of scholars, economists and policy makers over the relevance of Pentecostalism, particularly in relation to economics and development.

\section{Objectives and Significance of the Study}

The objective of this study is to examine the impacts of the rising trend of pentecostapreneurship in Nigeria on the promotion of the Nigeria's National Policy on Labour and Productivity (NPLP) as well as on the country's national development. Labour and productivity are essential to balancing the Gross Domestic Products (GDPs) and Gross National Products (GNPs) as well as Gross Domestic Income (GDI) and Gross National Income (GNI) of nations. Nigeria has Labour and Productivity Act which is geared toward the promotion and enhancement of efficient labour and service delivery in Nigeria. Thus, this study calls the attention of pentecostapreneurs, Pentecostal leaders and followers about the missing links to helping the body as well as their compatriots in arriving at individual and national demands on labour and service. Again, this research is useful to Pentecostals in Nigeria because it creates the awareness of the problems associated with the rising trend of pentecostapreneurship in Nigeria and helps them to overcome such challenges and arrive at the expected result that will be consistent with national and individual policies on labour and productivity, ethics and values.

\section{Pentecostapreneurship at the Service of Pentecostalism}

Pentecostapreneurship involves the activation and deployment of the individual's spiritual capital, especially, baptism in the Holy Spirit, empowerment and the gifts of the Holy Spirit as well as personal human capital to the Christian enterprise. It involves the living, the pursuit and full exploitation of individual's spiritual capital made available to Christians by the Holy Spirit at Pentecost. Like entrepreneurship, it involves identifying, discovering, utilizing and employing individual's spiritual capital (empowerment and gifts of the Holy Spirit) as well as personal human capital to the Christian enterprise. Like in business venture, this involves sourcing and organizing required energy, time, resources, risks and rewards associated with it toward the growth of the Christian faith.

Pentecostapreneurship derives its root and philosophy from the Pentecost experience in the Christian Bible (Acts chapter two). Here, it is interpreted that the Holy Spirit was given to followers of Jesus and through baptism with the Holy Spirit empowers them (gifts of the Holy Spirit) for Christian witnessing. In Pentecostal conceptualization, every born again Christian is empowered for Christian witnessing. For this reason, pentecostapreneurship has two levels of expression. The first level of expression drives some presumed born again Christians (Pentecostals) into active pastoral ministry as ministers with the assumption that the Holy empowers 
and calls them into such ministries. Such drive encourages the development of pastorpreneuship and evangeconomics. Pastorpreneurship is the business of using the word of God or God's name to make money, earn a living and/or extort money/other material goods from unsuspecting admirers and adherents. Evangeconomics is business in religion and business through religion and this operates like a franchise. A franchise is a kind of license that a franchisee obtains to allow him/her the right/privilege to use a franchiser's trademarks, processes and propriety knowledge in order to enable the party sell a product or provide a service under the business name. In Nigeria, some Pentecostal churches and figures (pastors) have acquired some popularity and thus, became a household name. Such churches and/or pastors use their popularity to expand their business empires in the name of churches via franchising. Franchising, here, is nothing but a strategy of expanding a business and distributing goods and services through a licensing relationship. Hence, individuals or groups of people who want to open churches and make something out it enter into franchising relationships and operate with popular church's or pastor's trademarks with a contractual pact on how to share the revenues accruing from it. Consequently, business wears the cloak of religion and operates with business principles and strategies. Pastorpreneurship and evangeconomics lead to commercialization of religion. Essien (2010: pp. 649-657) outlined various categories of the commercialization of the Christian religion and ministry and these include the commercialization of prosperity, fertility, salvation, prophecy, healing and deliverance, among others.

Pentecostapreneurship has two levels of expression. The first level of expression of pentecostapreneurship permits and encourages abdication of professional competence and specialization in favour of pastoral or religious ministries. The second level of expression drives assumed born again Christians (Pentecostals) to see themselves as special people of God who manifest their specialty by active and passionate participation and commitment to religious activities. This expression of commitment is often manifested symbolically (through vests, bangles, stickers), verbalization of identity (I am a Winners, a Redeemed, a Chosen, an OPM -Omega Power Ministry) and through practical religiosity by way of participation in religious programmes. The range of the programmes includes crusades, revivals, outreach, rallies, seminars, retreats, vigils, camping, religious conferences, workshops, religious tourism, door-to-door evangelism, family cleansing, town cleansing and weekly/ monthly services or ministrations, among others. This work takes a brief look at some of the programmes especially:

\section{a) Crusades}

In this context, a crusade is an organizational form of religious campaign through which born-again groups "reach out" to people with the Christian message and this is organized in a manner similar to military campaign. Ajani (2010: p. 109) notes that open air crusades have become a common phenomenon of Pentecostal Christianity in Nigeria. It has become so popular that almost all Christian denominations see it as an invaluable evangelization strategy. The months of November, December and January witness increasing number of crusades in Nigeria which are organized by different churches. Mainline churches, especially their charismatic renewal groups have also joined this popular Christian trend. The respondents to this study acknowledge that crusade is one of the remarkable outcomes of Pentecostalism, and a significant tool of Pentecostal evangelism.

Crusades are normally organized with some targets in view. The targets are captured in the themes that sell out the crusade to the public. The themes are captured in the language of miracle and prosperity. Ezema (2015) delineate some of the popular crusade themes in Nigeria. They include "From Poverty to Prosperity", "From Grass to Grace", "Success is my Portion”, "My time to Succeed has Come”, "Destined to have more than Enough”, “Unlimited Prosperity”, “New Millennium Break Through”, “Key to Successful Year” and so on. The complexities, challenges and confusions confronting people in their daily lives dispose or compel them to look for solutions. Religious ministers, especially Pentecostal ministers claim to proffer solution to most of the irreconcilable exigencies of life. Crusades form part of apparent fora through which churches/ministers give out, reach out and provide solutions and answers to those who need them. Crusades according to one respondent, Tom-George (2016) are therapeutic for those who are alienated from themselves, from the society and from others, for those who feel abandoned, harassed, disappointed, or betrayed. Each crusade proposes and in fact, guarantees what it tends to achieve and people congregate from different geographical locations in anticipation of solutions to their various material, spiritual, social, psychological and emotional needs. As human life is a theatre of endless complexities, and Africa nay Nigeria has little or no scientific or technological mechanisms through which to handle them, crusades have become unavoidable Christian alternative. For this reason, crusades, according to the interviewees, have become fashionable Christian culture in Nigeria, more especially for Pentecostal denominations. In the face of daunting socio-economic problems in Nigeria, crusades keep people 
busy and distract them from facing their challenges proactively. Instead of developing concrete action plans to mitigate their socio-economic conditions, most Nigerian people seek for quick and easy routes or shortcuts to success which the crusades promise. This informs why Obiora (1998: p. 73) remarks that a "Crusade is found to be a forum where well-fed individuals boast their ego, project false assumptions, dish out intriguing half truths, innuendo, understatements, exaggeration, inarticulate promises, insinuations, deliberate generalizing and distortion of facts, false testimonies, and imputation for improper motives”. But in spite of this, crusades continue to prosper in Nigeria. In his assessment, Olatunji (2016) notes; "As a result of the overwhelming ignorance, blindness and gullibility of most Nigerian people, religious ministers/churches continue to hype the game and saturate the environment with crusades upon crusades, in season and out of season". Whereas the anxiety related to salvation drove Calvinist Protestants to active engagement in daily affairs; socio-economic problems and challenges rather than drive most Nigerian people into the field of work drove them to crusades and churches.

Crusades are time consuming and capital intensive. Some crusades last for a week or two weeks as the case may be. A lot of preparation and publicity go into the planning and hosting of a crusade. Indeed, time, money, resources and energy are spent in organizing, hosting and managing a crusade. In relation to publicity, all available forms of media and communication strategies are deployed to create awareness and to prepare people ahead of each crusade.

\section{b) Revival}

Revival is a derivative of the word "revive", which means to restore to life or consciousness (Okechukwu, 2013: p. 25). In Christian context, revival refers to a specific period of spiritual renewal in the life of a Christian, a group or denomination. It refers to a period of spiritual reawakening, especially from a state of perceived or apparent spiritual dormancy or stagnation in the life of a Christian, a group, a denomination or a church. According to Okechukwu (2013: p. 13), "Revival is meant to invigorate and deepen the faith of a Christian, a group of people and opening his/her or their eyes to the truth in new and dynamic way”. By and large, revival involves the connotation of a fresh start with a clean slate, marking a new beginning of a life lived in obedience to God. In fact, revivals are meant to instil new life into the target group or audience. It is also often used as a tool to inspire or renew a group's or people's commitment to God and to the church. Revivals, usually, focus on appeals to the imagination, exciting emotions and gratifying the love for what is new and startling. For this reason, it attracts thousands of people from different locations who yearn for something new.

Just like crusade, revivals have become a common Pentecostal phenomenon, especially in Nigeria. Revivals have become so common that often no weekend passes in Nigeria without some Pentecostal group organizing one revival or another. Some of the respondents acknowledge that Nigeria has been experiencing a surge in Christian religious revivals within the last twenty years. They are reported, according to the most of the interviewees, in towns and cities throughout the country, especially in Lagos, Port Harcourt, Ibadan, Onitsha and Enugu, among others. Some mega Pentecostal churches in Nigerian hold monthly revivals along the Lagos-Sagamu-Ibadan expressway. This road is the only dual carriage road that connects Lagos and other states in the South-east, South-west and South-south of Nigeria. The monthly Holy Ghost revival programme of the Redeemed Christian Church of God (RCCG), for instance, is one of such examples. Some of the respondents points out that the traffic gridlocks experience associated with these revivals constitute a significant nuisance factor and sometimes safety hazard to motorists and surrounding neighbourhood.

\section{c) Outreach}

Outreach is a kind of promotional service or awareness about a product, a programme or a group. Traditionally, outreach is an activity of providing services to populations who might not otherwise have access to those services. Outreach teams are sent to different or intended locations to advertise or undertake awareness promotions. Of course, a key component of outreach is that individuals or groups providing a particular service are not stationary but mobile. In other words, they move from place to place with the intention of finding and meeting those in need or those perceived to be in need of their services at their locations.

Compared to traditional service providers, outreach services are brought to people at the doorpost of their convenience and reach. It is used as a means of creating awareness about existing products, services, programmes or of a group or institution. In the religious parlance, outreach is a significant evangelization strategy which is used to sell out or advertise a religious group and/or their programmes to the public. According to one of the interviewee, Omeh (2016), "Outreach is a crucial proselytization tool. We design outreach programmes to target various population demographics, from market men and women, students, peasant workers, drug addicts, sex workers, motor park workers and so forth”. Indeed, most Pentecostal churches in Nigeria exploit the use of out- 
reach for proselytization and it serves as a tool for winning converts and increasing the numerical strength of their churches. In fact, outreach is one of the aggressive evangelization strategy introduced by Pentecostal churches in the face of competition in order to establish a presence, create awareness, win converts and gain some control of the Nigerian religious space.

Rhodes (1996: pp. 25-26) identifies three types of outreach. They include domiciliary, detached and peripatetic forms of outreach. Domiciliary outreach is the outreach carried out at individual residential homes. Detached outreach is the type of outreach carried to a public environment. It concentrates at reaching individuals at public environments. Peripatetic outreach takes place at public or private environments with the intention of reaching organizations rather than individuals. Of the three types of outreach outlined by Rhodes, domiciliary and detached types are common in Nigeria religious space. The interviewees acknowledge that market places, significant public spaces, bus stops, train stations, motor parks, community or village squares and busy junctions are centres of attraction for Pentecostal outreach in Nigeria.

\section{d) Vigil}

The word "vigil" came from the Latin root vigilia meaning wakefulness indicating a period of purposeful sleeplessness, an occasion for devotional watching, or an observance. In fact, vigil is a time of vigilance, wakefulness, a watch normally kept at night. Vigils make the nights more radiant than the day (Cross \& Livingstone, 2005: p. 600). Vigils enable Christians to step out of time and move into eternity. It offers people time to pray more and also to have undistracted moment of communication with the supernatural being or reality. Vigil can be an individual or organized group phenomenon. Both individual and organized group vigils exist in Nigeria religious environment, especially among Christians.

Vigils have been characteristic part of all Christian traditions. It can be scheduled for a whole night, or before mid-night, or some hours before dawn according to needs and convenience. In traditional Christianity, vigils are held on the eve of major religious festivals or feast days, such that vigils are regarded as watchful devotional exercise or ritual observances on the eve of a holy day. The popular vigils in traditional Christianity are the Easter Vigil normally held on Holy Saturday or the Christmas Eve which is usually held on $24^{\text {th }}$ December, among others. Vigils are also held when someone is gravely ill or mourning or when people have some grave issues bothering them. It also extends from eventual death to the burial of a Christian in which they gather to pray ritualistically for a dead loved one. Singing of psalms, prayers, worship songs, hymns and sermons or preaching, and sometimes silent meditations usually form the activities that characterize vigils.

As already noted, vigils are held, usually on the eve of major Christian festivals or feasts or when serious issues arise. However, with the emergence of Pentecostalism, vigils have been redefined and have taken a new dimension in the economy of Christian spirituality and religious expression. In fact, what is regarded by some scholars (Achunike, 2004; Anderson, 2004; Dim, 2012) as the first official outburst of Pentecostalism started with an all-night programme at Azusa Street, Los Angeles in 1906 under William Joseph Seymour (1870-1922). They prayed, sang, danced, shouted, spoke in tongues all through the night (Dim, 2012: pp. 6-7). Since then, vigils have become characteristic part of most Pentecostal groups or Pentecostal-oriented groups such as those belonging to various Charismatic Movements outside and within the mainline churches and other independent ministries and churches. In Nigeria, vigils have become a common and regular Pentecostal religious expression. Vigils are usually organized by most Pentecostal churches in Nigeria on weekly, fortnightly or monthly basis. According to some of the interviewees, vigils held by major Pentecostal churches/denominations in Nigeria or organized by some so called "influential men of God" attract large numbers of people. Most of the vigils are usually held on Wednesdays, Thursdays or Fridays depending on the group, minister or church organizing it. In a highly competitive religious environment as we have in Nigeria, churches and ministers compete with the number of vigils they roll out every now and then.

Of course, participation in vigils affects people's efficiency, attentiveness to duty and general productivity input and consequent output. Nature abhors a vacuum. It follows a process and this process cannot be compromised or cheated without grave consequences. Adequate rest and sleep is indispensable to human efficiency, attentiveness to duty and optimal productivity input and output. This informs why deprivation of rest or sleep, especially night rest is counterproductive both to the individual and the society at large. If people were to spend much of their time attending to religious vigils, it will definitely affect them negatively. What such people deprived of nature, it takes back from them a hundredfold the next day and this is usually in the field of work and during work hours. Majority, if not all of such people spend the whole day sleeping or rendered totally ineffective and useless, until the sleep they lost was adequately supplied. The reason for this is simply because nature 
cannot be cheated. Obong (2016) notes, “Once I attend a vigil, the subsequent day and even the next would be useless for me. I will be feeling stressed up and uncoordinated and my productivity very low until I pay back what I lost”.

Vigils have boundless impacts. It affects attendees as well as non-attendees within a particular environment. It affects attendees directly because they willingly and voluntarily attended such programmes. It affects non-attendees indirectly, since although, they did not attend such programmes, they were all the same deprived of the peace and rest they should have enjoyed in their neighbourhood. Vigils are characterized by loud singing, usage of musical instruments and ear jarring drum-sized microphones, megaphones and loud speakers. Night-hour religious activities generate intense and such penetrating noise effects that prevent people within the surrounding neighbourhood from experiencing satisfactory night rest. In fact, the noise that such services produce, affects everyone within the environment and beyond. Residents of urban cities suffer most from the effects of noise pollution as a result of heavy concentration of Pentecostal churches in such areas. Often, there are clusters of Pentecostal churches within residential areas. Omeh (2016) notes that a single street could have as many as ten to fifteen different churches or more. Even worse, there are some places where a number of churches co-exist in the same building. Olatunji (2016), who incidentally is medical personnel, indicates that such noise pollution and their consequent effects, especially, deprivation of sleep can lead to stress-induced ailments such as hypertension, diabetes and psychiatric problems, among others. These affect the overall efficiency, attentiveness to duty and general productivity input and output of both attendees and non-attendees.

\section{e) Retreat}

A retreat is a term borrowed from military vocabulary. In military language, a retreat involves an act of withdrawing or moving back of a battalion in order to have time for assessment and re-strategization for effective military output. In religious parlance, a retreat is typically defined as a journey taken away from the confines of everyday living, activity or schedule in order to have a moment of inward assessment of one's life and his relationship with God. Retreats are undertaken for the purpose of spiritual growth or rebirth, of improving one's relationship with God, of rediscovering one's faith, of personal purification and atonement. It gives individuals or groups opportunity for spiritual renewal. Such periods are devoted to studying the Scripture and other religious texts, prayer, meditation and rest (Okechukwu, 2013: p. 24). In this sense, when a person is undergoing a retreat, it implies he is withdrawing from the society to a quiet time of solitude and silence to engage in some spiritual or religious exercises. Religious retreats can be as simple as a weekend camping or as complicated as travelling to a distant location. Retreats, more often than not, cover a period of a few days to one week and in rare cases for a period of one month. Religious houses, churches, monasteries, retreat centres or a journey into the desert are popular locations for retreats.

Retreats are integral part of many world religions such as Hinduism, Buddhism, Christianity and Sufism (Islamic). However, retreats are much more popular in Christian tradition. As a medium for deepening the faith of members, many Christian denominations and groups have adopted retreats as a recurrent religious exercise and have exploited it to their advantage. Through retreats, they offer their members the opportunity to come together, pray, discuss and evaluate and nourish their faith.

\section{f) Healing/Anointing/breakthrough Services}

Apart from organizing crusades, vigils, religious rallies, revivals, retreats, most Christian churches, especially, Pentecostal churches and independent ministries in Nigeria also hold special weekly prayer sections or ministration services that run through a whole day. Each of the churches or ministries selects a particular day in a week to hold such special prayer section or "ministration services" under various tags or names with the purposes of bringing healing, anointing, breakthrough, and prosperity to its members. In the Catholic Church, for instance, it is often called "ministry of the sick" and some others call it adoration. In Pentecostal circles or independent ministries, it comes under different names. Any day of the week from Monday to Friday is usually chosen for such services or ministrations regardless of whether it interferes with productive hours or not. Unfortunately, it does interfere with productive hours. In the course of this research, all Christian churches or ministries visited without except have a particular day of the week they hold such programmes. The interviewees also consented to this fact. Observations in the course of the research reveal that attendance to prayer sections and ministration services in these churches/ministries are significantly dominated by the socially and economically disadvantaged people. The poor, needy, unemployed persons, sick people, women and children dominate the audience. Odoguje (2016) reveals that people in such social and economic conditions often spend valuable time and energy prostituting in the programmes held by various churches and ministries. The desperation associated with 
poverty, hardship or sickness has made some people to move from one church or ministry to the other in search of solutions. The researcher and co-researchers came face-to-face with people who admit that they often occupy a whole week with the habit of moving from one church service to another. One of the attendees, Anthony (2016) asserts that she attends prayer sections and/or ministration of different churches with the conviction that if a solution is not found in one place; it might be found in another since nobody knows where salvation will come from.

\section{Pentecostapreneurship and National Development}

National development involves the qualitative and quantitative growth or transformation of a nation that cut across the economic, social, cultural, political, scientific, moral, and ethical as well as the environmental landscape of a nation. It is a comprehensive transformation that fairly touches every aspect of the life of a nation. To achieve this objective, the synergy between religion, proper management of time, hard work, science and technology must be justifiable maintained in societies for a balanced human and societal development. Against this backdrop, it is, however, worrisome in Nigeria where Pentecostalism advocates superstition instead of science; proliferation of churches instead of growth of industries and technological advancement; cheap escapism through multiplicity of religious activities rather than dedication to duty or acquisition and development of skills, among others. Pentecostapreneurship disposes Pentecostals in Nigeria toward multiplicity of religious programmes either as participants or architects and promoters of religious programmes. While the architects and promoters serve as the supply side of religious industries, the participants stand as the demand side or consumers of the output of the supply side. The supply side of this economy is very active and responsive to the gullibility of the demand side. This responsiveness on the part of the supply side is manifested in the proliferation of churches and multiplicity of religious programmes and these have become a popular trend in Nigeria. Forty-five (45) respondents out of the fifty (50) people interviewed for this study attest that Pentecostal churches in Nigeria churn out countless numbers of religious programmes and activities ranging from crusades, revivals, outreach, rallies, seminars, retreats, vigils, camping, religious conferences, workshops, religious tourism, door-to-door evangelism, family cleansing, town cleansing and weekly/monthly services or ministrations, among others, as explained above. These programmes, the respondents note, keep their members busy and out of productive ventures. Quality and productive hours, human energy and even resources are dissipated and lost to religious programmes and/ or activities. Many religious suppliers, including people who abdicate their professional competence engage quality time in the name of doing God's work. The table (Table 1) below shows the list of some professionals in Nigeria that abdicated their professional specialization for pentecostapreneurship.

Moreso, many religious consumers, especially the poor, compromise productive hours while attending or engaging in religious programmes. In either of the cases, one wonders what such attitudes to life add to the growth and survival of such individuals and by extension to Nigerian economy. But what is obvious is that productive hours are wasted and nothing is added to the economy either by way of taxes or of production of goods and services.

But in contrast to the above scenario, one of the distinctive aspects of national development is the enhancement and assurance of economic growth. Economic growth consists, among other things, of a positive change in

Table 1. Professionals that abdicated their specializations for pentecostapreneurship.

\begin{tabular}{lcc}
\hline Name of Pastor & Church & Specialization \\
Tunde Bakare & Later Rain Christian Assembly & Lawyer \\
Chris OKotie & Household of God Church & Lawyer \\
Enoch Adeboye & RCC & Applied Mathematics \\
D. K. Olukoye & Mountain and Fire and Miracles Ministries & Architect \\
David Oyedepo & Living Faith Church & Mathematics \\
W. F. Kumuyi & Deeper Life Christian Ministry &
\end{tabular}

(Source: culled from Nigerian Bulletin news online.com). 
the output or production of a country or economy and this involves all aspects of an economy, from profits to taxes and wages and to such things as production rates. Economic growth is significantly measured by the Gross Domestic Product (GDP) and Gross Domestic Income (GDI) rates of a country. Indeed, part of the indicators of economic growth is increase in production, which means increased profits for the production companies. Increase in production also translates to increase in tax collection rates for the government. It also entails reduction in unemployment and poverty levels, and better prospects for the citizens and the economy. Indeed, positive economic growth leads to increased prosperity for the citizens and the creation of a healthy economy.

Engagement in productive ventures, according to Ihedioha (2016) leads individuals to develop their potentials, skills and capabilities and above all, leads to the development of industries. Developed countries are growing richer quite rapidly while underdeveloped countries for the most part show stagnancy or slow rates of growth. In contrast to underdeveloped economies, developed economies are commendably industrialized. That is to say, greater part of their working population is engaged in industry and most if not the greater part of their wealth comes out of mines and factories. They have a high output of labour per man in industry (Rodney, 1972/2009: p. 18). On the contrary, underdeveloped economies often concentrate on those services that do not in turn generate growth or raise production level. They often focus on service-oriented engagements that yield no productive outcome. That is informs why developed countries have better economies than underdeveloped countries. Indeed, most service-oriented economies rather than create wealth only dissipate available resources within the country. Service-oriented institutions squander the wealth created by peasants and workers in purchasing exotic cars or aircraft, multi-million church buildings, luxury homes, whisky and perfumes, among others and these do not add any meaningful economic value to the society. In Nigeria, for instance, some Pentecostal clergy men who make fortunes through pentecostapreneurship and pastorpreneurship dissipate such resources in acquisition of unnecessary material goods such as aircrafts. Table 2 below shows some Nigerian pastors that own aircrafts even in the midst of the excruciating poverty in the country

As a service venture, churches often do not engage in productive ventures and pay no taxes to the government. The churches are treated as non-profit institutions in Nigeria (even though they generate so much money through tithes, offerings, fundraising and donations) and consequently, do not pay property and other taxes. In 2014, a motion was raised on the floor of the Nigerian Senate whether churches should pay taxes or not since they generate so much and exhibit great affluence. A consensus was not reached on the debate except for churches to pay taxes on the business they run. Implicitly, if Nigeria was to depend on property taxes to drive government revenues, she would lose money on the property owned by churches or other houses of worship (temple, synagogue, mosque, or shrine).

However, for a country to achieve economic growth and tread on the path of sustainable national development, it has to develop industries, produce goods and services that will in turn generate future growth within the economy. Consequently, entrepreneurship is exceedingly more beneficial to national development that pentecostapreneurship. Extended impacts and results of entrepreneurship and entrepreneurial initiatives are found in the emergence of industries and development of human creative potentials. Similarly, the extended impacts and results of pentecostapreneurship and pentecostapreneurial initiatives are manifested in the multiplicity of reli-

Table 2. Nigerian pastors that own aircrafts.

\begin{tabular}{lcc}
\hline Name of Pastor & Name of Church & Number of Aircrafts \\
David Oyedepo & Living Faith Church & 5 \\
Enoch Adebayo & RCCG & SCOAN \\
T. B. Joshua & WLBC & 1 \\
Ayo Oritsejafor & TREM & 1 \\
Mike Okonkwo & Love World Ministries & 1 \\
Chris Oyakilome & Daystar Christian Center & 1 \\
Sam. Adeyemi & KICC \\
\hline
\end{tabular}

(Culled from Nigerian Bulletin online news/vanguardngr.com). 
gious programmes, abdication of professional competence or specialization in favour of religious ministries, abuse of productive hours, growth and entrenchment of the culture of indolence and pastorpreneuship, among others. Of the two outcomes, generation of industries is much more beneficial to national development than proliferation of churches or multiplicity of religious activities. Creation of industries within a nation is favourable to the development of the nation. Industries reduce the poverty level in a country by providing productive employment to people and this inevitably improves the GDP and GDI rates of the country. Through the creation of industries, individuals and nations create wealth. The wealth so created serves the interests of the individual and their families/friends, those of others and nation or country at large. Industries/businesses pay taxes to the government and these revenues keep the government going and the nation functional. On the contrary, keeping people busy with activities other than work and diverting their energies away from productive engagements is unfavourable to human and societal development. Majority of the respondents (38 out of the 50 persons) interviewed in the course of this study on what constitutes genuine manifestation of religiosity among Pentecostals in Nigeria (whether active participation in their duties or participation in religious programmes) note that active participation in religious programmes is one of the most indisputable expression of religiosity. Only twelve (12) respondents subscribe to the view that active engagement in their duties is the authentic expression of religiosity. Forty-two (42) respondents also underscore that the religious programmes' schedules of majority of the Pentecostal churches interfere with productive hours ( $8 \mathrm{am}-4 \mathrm{pm})$. Majority of the respondents reflect the opinion that pentecostapreneurship keeps people away from active engagement in their duties in the world and keeps them busy with participation in religious programmes. This has negative implications for national development since productivity is not enhanced and the realization of the Nigerian National Policy on Labour and Productivity (NPLP) is adversely undermined.

Undeniably, one important measure of national development is that of economic growth and productivity in a country. Economic growth in its turn is evaluated through the GDP growth rate of the country. A country's GDP is made up of the monetary value of the goods and services produced in a country in a year (Giddens, 2009: p. 527). Measures of economic activity with reference to GDP and GDI are given per person. This allows nations to compare the wealth of an average inhabitant of a country. Hence, keeping people away from active engagement in productive ventures and economic activities, no doubt, undercuts national development since it affects productivity output and unavoidably, leads to low GDP, GDI, GNP and GNI rates in Nigerian economy. Figure 1 below shows the Central Bank of Nigeria (CBN)'s report on GDP growth rates in Nigeria from 2013 to 2016.

The Central Bank of Nigerian report covering 2013-2016 shows that Nigeria GDP growth rate contracted 13.70 percent in the first quarter of 2016 over the previous quarter. The GDP growth rate in Nigeria averaged 0.30 percent from 2013 until 2016, reaching an all time high of 9.19 percent in the third quarter of 2015 and a record low of -13.70 percent in the first quarter of 2016. The point this study underscores is that keeping people out

NIGERIA GDP GROWTH RATE

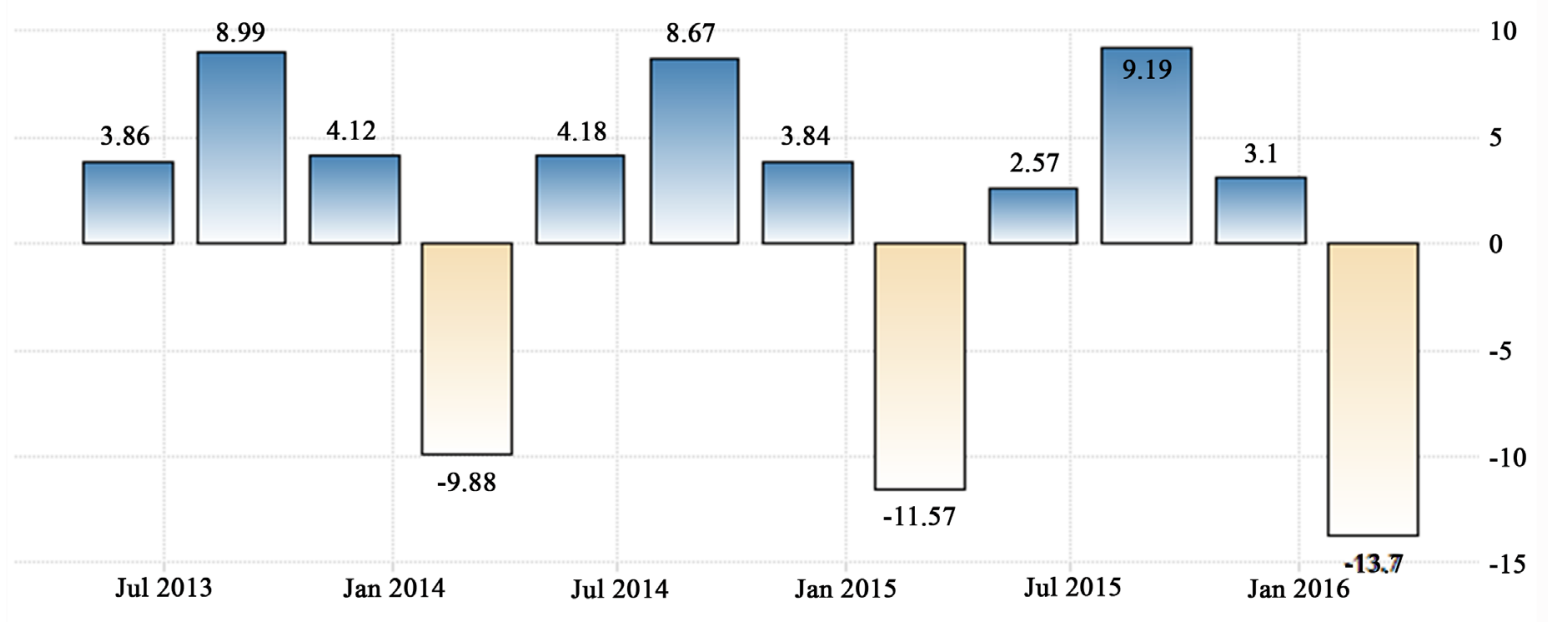

SOURCE: WWW.TRADINGECONOMICS.COM CENTRAL BANK OF NIGERIA 
productive ventures and engage them with religious programmes contributes to Nigeria's low GDP growth rates. In Achunike (2004: p. 6)'s opinion, planting new Pentecostal churches and selling petrol are the only two things viable in Nigeria. Planting new churches and multiplying religious programmes have no functional economic value but adverse economic impacts. Keeping adherents in the churches through religious programmes and away from productive engagements undermines productivity output. Hence, in a country where majority of the citizens spend more time at prayer camps or attend deliverance ritual centres rather than in the field of work; such a country will certainly experience low productivity out as well as low GPD, GDI, GNP and GNI rates. Religious groups/denominations concentrate more on human-supernatural service delivery (worship services, crusades, revivals, retreats, prayer hours) and this often yields no economic gain to individuals and societies. Such services dispose people toward the culture of indolence, abuse of productive hours and strangulation of human creative potentials and these are antithetical to human and societal development and wealth creation. The long term outcome of this is nothing but underdevelopment.

\section{Conclusion}

Pentecostapreneurship makes proliferation of churches and multiplicity of church programmes a popular culture in Nigeria. Consequently, there is a considerable growth in the number of pastors and pastoral workers in Nigeria as well as proliferation of churches (Obiora, 1998). Greater number of Nigerians is joining the religious ministries and opening churches to service the religious industries. Regrettably, this impedes the development of human potential and possible growth of industries. No doubt, the attraction associated with the religious ministry in Nigeria as sources of income and social mobility seduces people and lures them to take up pastoral jobs. Unfortunately, such jobs render them economically impotent and unproductive, thereby stifling or strangulating their creative potentials. In so doing human and societal development is in the long run undermined.

\section{References}

Achunike, H. C. (2004). The Influence of Pentecostalism on Catholic Priests and Seminarians in Nigeria. Onitsha: African First Publishers Limited.

Ajani, E. (2010). Reinhard Bonnke’s Crusades in Nigeria: Cultural Adaptation or Evangelical Renewal? In D. O. Ogungbile, \& , A. E. Akinade (Eds.), Creativity and Change in Nigerian Christianity (pp. 109). Lagos: Malthouse Press Limited.

Anderson, A. (2004). An Introduction to Pentecostalism. Cambridge: Cambridge University Press.

Anthony, O. (2016). Oral Interview on Pentecostalism in Nigeria.

Barker, I. (2007). Charismatic Economies: Pentecostalism, Economic Restructuring, and Social Reproduction. New Political Science, 29, 407-427. http://dx.doi.org/10.1080/07393140701688305

Barrett, D., \& Johnson, T. (2001). Annual Statistical Table on Global Mission: 2001. International Bulletin of Missionary Research, 25, 25. http://dx.doi.org/10.1177/239693930102500106

Berger, P. (2008). Faith and Development: A Global Perspective. http://www.cde.org.za/wp-content/uploads/2013/02/Faith_and_Development.pdf

Cross, F. L., \& Livingstone, E. A. (Eds.) (2005). The Oxford Dictionary of the Christian Church. Oxford: Oxford University Press. http://dx.doi.org/10.1093/acref/9780192802903.001.0001

Dim, E. U. (2012). Pentecostalism and Its Challenges: The Pertinent Questions. Lagos: Sovereign Prints Nigeria Limited.

Ezema, V. (2015). Oral Interview on Pentecostalism in Nigeria.

Giddens, A. (2009). Sociology (6th ed.). New Delhi: Wiley India Pvt. Ltd.

Ihedioha, E. (2016). Oral Interview on Pentecostalism in Nigeria.

Ihejirika, W. C. (2004). An Audience Ethnography on the Role of the Mass Media in the Process of Conversion of Catholics to the Pentecostal Churches in Nigeria. Roma: Pontificia Universita Gregoriana.

Mbachirin, A. T. (2006). The Responses of the Church in Nigeria to Socio-Economic, Political and Religious Problems in Nigeria: A Case Study of the Christian Association of Nigeria (CAN). https://baylor-ir.tdl.org/baylor-ir/handle/2104/4874

Mbiti, J. (1969). African Religions and Philosophy. New York: Frederick A. Praeger.

Obiora, F. K. (1998). The Divine Deceit: Business in Religion. Enugu: Optimal Publishers.

Obong, A. (2016). Oral Interview on Pentecostalism in Nigeria.

Odoguje, M. (2016). Oral Interview on Pentecostalism in Nigeria. 
Okechukwu, J. (2013). The Changing Face of Christianity in Nigeria. Onitsha: Edeji Press.

Olatunji, D. (2016). Oral Interview on Pentecostalism in Nigeria.

Omeh, C. (2016). Oral Interview on Pentecostalism in Nigeria.

Rhodes, T. (1996). Outreach Work with Drug Users: Principles and Practice. Council of Europe.

Rodney, W. (1972/2009). How Europe Underdeveloped Africa. Lagos: Panaf Publishing.

Tom-George, T. (2016). Oral Interview on Pentecostalism in Nigeria.

\section{Submit or recommend next manuscript to SCIRP and we will provide best service for you:}

Accepting pre-submission inquiries through Email, Facebook, LinkedIn, Twitter, etc. A wide selection of journals (inclusive of 9 subjects, more than 200 journals)

Providing 24-hour high-quality service

User-friendly online submission system

Fair and swift peer-review system

Efficient typesetting and proofreading procedure

Display of the result of downloads and visits, as well as the number of cited articles

Maximum dissemination of your research work

Submit your manuscript at: http://papersubmission.scirp.org/ 